\title{
HOGYAN KÉSZÜL EGY JELNYELVI (SZLENG)SZÓTÁR?
}

\author{
Szerző: \\ Bodnár Noémi (Drs) \\ Eötvös Loránd Tudományegyetem
}

Szerző e-mail címe:

bodnarnoemi@gmail.com

\section{Lektorok:}

Katona Krisztina $(\mathrm{PhD})$

Gál Ferenc Egyetem

Mező Ferenc (PhD)

Eszterházy Károly Egyetem

...és további két anonim lektor

\begin{abstract}
Absztrakt
A jelen tanulmány célja a jelnyelvészeti kutatások rövid áttekintése után a jelnyelvi szleng egy lehetséges meghatározásának bemutatása, az eddig elkészült jelnyelvi szótárak áttekintése, valamint a jelnyelvi anyaggyüjtés kérdéseinek áttekintése, végül pedig egy saját kutatás bemutatása
\end{abstract}

Kulcsszavak: jelnyelv, szleng, szótár

Diszciplina: pedagógia

\section{Abstract}

HOW IS A SIGN LANGUAGE (SLANG) DICTIONARY MADE?

The aim of the present study is to present a possible definition of sign language slang after a brief review of sign language research, to review the sign language dictionaries completed so far, and to review the issues of sign language collection, and finally to present one's own research.

Keywords: sign language, slang, dictionary

Discipline: pedagogy

Bodnár Noémi (2020): Hogyan készül egy jelnyelvi (szleng)szótár? OxIPO - interdiszciplináris tudományos folyóirat, 2020/3, 87-96. doi: 10.35405/OXIPO.2020.3.87 
A jelnyelvkutatás viszonylag fiatal tudomány, Amerikában az 1960-as években indult el és William C. Stokoe nevéhez füzhető, ő ismerte fel, hogy a jelnyelv természetes, teljes értékű nyelv. Az 1960ban megjelenő Sign Language Structure: $A n$ Outline of Visual Communication Systems of the American Deaf című munkája világszerte felkeltette a jelnyelv iránti érdeklődést. Hazánkban 1994-ben, a SINOSZ koordinálásával indultak el a jelnyelvi kutatások.

A jelnyelvi szlengkutatásnak még nem alakult ki bőséges szakirodalma, viszont mivel a szleng nyelvi univerzálé (Penttinen; 1984:7; Tender 1997; Kis 2006), feltételezhető, hogy a jelnyelv használói körében is kialakult és él.

Amerikában 2014-ben szerveztek jelnyelvoktatók részére egy továbbképzést, melynek során kifejezetten az amerikai jelnyelvi szlengre koncentráltak

A wsrid.com oldalon található jelnyelvi továbbképzés meghívóban (Net1) olvasható a következő szövegrészlet:

„This workshop will provide participants an opportunity to learn some of the newest and often used ASL slang signs and colloquialisms and their meanings."

Azaz:

„Ez a workshop lehetőséget nyújt a résztvevőknek arra, hogy elsajátítsanak néhány új és népszerű kollokviális és szleng elemet az amerikai jelnyelvből".
Több siket vlogger is utal a jelnyelvi szleng létezésére (Vö.: Net2, Net3). Rövidebb internetes cikkek is szólnak mind a külföldi, mind a magyar jelnyelvi szlengről - például: Sheffield, Duncan és Strasser (2015), Jaxon (s.a.), Iván Viktória (2014) „Így küld el a fenébe egy siket ember”.

A jelnyelvben a szleng fogalmát csak részben lehet a hangzó nyelvekre irányuló nyelvészeti kutatások mentén meghatározni, ezért fontos meghatározni azt, hogy a jelnyelv mely elemei tekinthetők szlengnek. A jelnyelvi szlenget aligha lehet a jelnyelv standard változatához képest meghatározni, hiszen a jelnyelv standardizációja jelenleg is zajlik.

Pavol Odaloš (1999, 42. o.) szerint „A szlengizmusok egyfajta aktualizációs szándék eredményeként jelentkeznek a kommunikációban. A szlengizmusok aktualizációs szerepével szorosan összefügg változatosságuk és nagyfokú expresszivitásuk". Ez az expresszivitás meghatározó volt a jelek gyújtése során. Kis Tamás (1992, 345. o.) katonai szlengszótárban így ír: „szleng az, amit a beszélője annak érez". Ez a meghatározás olyan szempontból hasznos, hogy a nyelvhasználók állnak a középpontjában, így a jelen gyüjtés során is jól alkalmazhatónak bizonyult. „Vannak úgynevezett siketes jelek, amelyek gyakran 2-3-4-5 szót is képesek egy jelben tömöríteni, vagy egy cselekvést egy jelben megjeleníteni” (Iván, 2014). Ezeket másképp jelnyelvi idiómáknak nevezzük. Baranyai András és Vincze Tamás nevéhez kapcsolódik a Beszél a Kéz című, első- 
sorban gyerekeknek szóló ismeretterjesztő könyvsorozat harmadik részeként 2007ben megjelent Vaker címú könyv, mely jelnyelvi idiómák gyűjteménye. A könyv fülszövegében a következők állnak: „A Beszél a Kéz sorozat harmadik részében a fiatalok rengeteg, mostanában használatos kifejezéssel ismerkedhetnek meg és mindezek mellett kézjelüket is elsajátíthatják."

A „mostanában használatos kifejezés” meghatározás megengedi azt a felvetést, hogy ezek voltaképp szleng elemek. Olyan szempontból is a szlenghez kapcsolhatjuk az idiómákat, hogy nagyon súrítettek, nagyon kifejezőek, mindig nagy érzelmi többletet hordoznak a köznyelvi megfelelőjükhöz képest. A siketes jel elnevezés az idiómák közösségi jellegét hangsúlyozza, a szlengre pedig jellemző, hogy egy adott közösség tagjainak összetartozását erősíti.
A jelnyelvi idiómákat (bár nem a jelnyelvi szleng részének tekintve) a külföldi kutatások már érintik (például: Hines. 2015) és léteznek jelnyelvi idiómagyűjtemények is. Ezek az idiómagyűjtemények nem mindig hozzáférhetők széles körben (lásd például: Net4). Léteznek olyan cikkek is, amelyek nem illusztrálják vizuálisan a jelelés módját, csak leírják a jelek kivitelezését (Panse, 2012). Létezik megvásárolható Idioms \& Phrases in American Sign Language címú DVD-sorozat is, valamint ingyenesen hozzáférhető online jelnyelvi szótár (Net5), ahol találhatók jelnyelvi idiómák. A magyar jelnyelv idiómáiról eddig még nem készült gyűjtemény.

Mivel a jelnyelv vizuális nyelv, jelnyelvi szótárat alkotni csak ezt a tulajdonságát figyelembe véve lehet (v.ö.: 1. ábra).

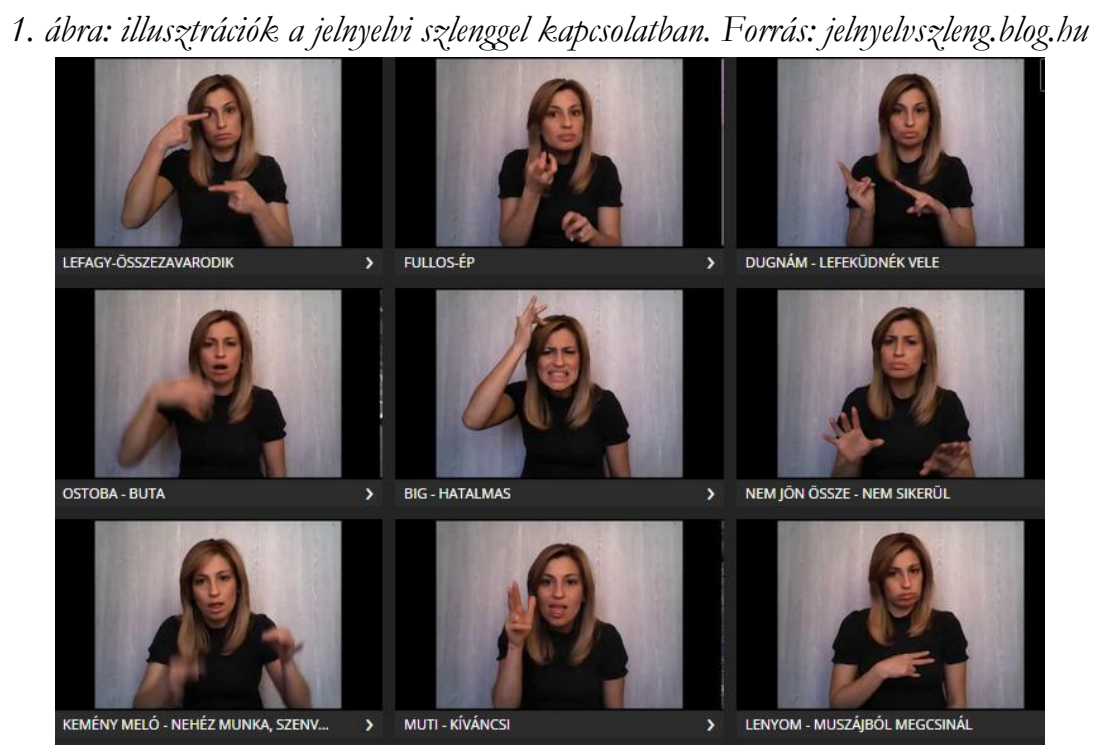


Számos jelnyelvi szótár létezik, néhány példa a teljesség igénye nélkül: az amerikai American Sign Language Dictionary (Sternberg, 1998), a francia La langue des signes sorozat második kötete (Moody, 1986), a görög Systema hellenikon neumaton (Triantaphullides, 1987), az olasz Dizionario bilingue elementare della lingua italiana dei segni (Radutzky, 1992), stb.

Amerikában 2011-ben megjelent egy Dirty Sign Language: Everyday Slang from „What's Up?” to „F*o\# Off!” (Dirty Everyday Slang) címú jelszótár (Van James és Allison, 2011), amely számos jelnyelvi szleng kifejezést gyújtött össze olyan témakörökből, mint például a bulizás, flört, sport, emberi kapcsolatok, szexualitás. Ez a kötet jó kiindulási pont lehet egy hasonló magyar jelnyelvi szlenget leíró kötethez.

A magyarországi kutatók közül Lancz Edina (1999) alkotta meg A magyar jelnyelv szótárát. Ebben a munkában a kézformák adják a rendszerezés alapját. Habár kétségtelenül hatalmas gyüjtőmunka eredménye e szótár, sajnos a munka egyáltalán nem teljes, inkább csak egy rövid kivonat a jelnyelv néhány eleméről. Ez a hiányosság abból adódik, hogy nyomtatott formában nagyon körülményes bemutatni a jelnyelvet, Lancz (1999) - jellemzően a jelnyelvi szótárak szerzőire - fotókkal szemlélteti a jeleket, és valóban ez tűnik a legszerencsésebb eljárásnak ilyen munkák esetében, hiszen a jelnyelvnek nem igazán van egy egységes, kidolgozott, jól mûködő lejegyzési rendszere.
Egy másik lehetséges út a jelnyelvi szótárak létrehozására az online videoszótárak alkotása. Az ilyen jellegű szótáraknak számos előnyük van a nyomtatott változatokkal szemben: könnyen hozzáférhetők, folyamatosan fejleszthetők, bővíthetők, pontosabbak, szemléletesebbek, épp ezért talán eredményesebben használhatók. A legnagyobb videoszótár a Spread the sign nevü (Net6), amely egy rendkívül jól rendszerezett és bőséges nemzetközi jelnyelvi adatbázis.

A hazai gyakorlatban is jelen vannak az online jelnyelvi szótárak, például a Hallatlan Alapítvány jelnyelvi szótára (Net7), vagy a JelEsély jelnyelvi szótár (Net8). A Hallatlan Alapítvány szótára tematikus csoportokba rendezett jeleket tartalmaz, a JelEsély jelnyelvi szótár jelei viszont kereshetők fő kézforma, alkézforma, kivitelezési hely, a jel típusa, mozgás típusa, mozgás iránya, jelnyelvi változat terület szerint, valamint a felvétel típusa szerint. E változatos keresési szempontok nagyon előnyösek egy online szótár esetén, megkönnyítik a jelek közötti tájékozódást. A magyar jelnyelvi szlengszótár is videoszótár formában, online platformon mûködhet igazán eredményesen.

\section{MÓDSZERTAN}

A jelnyelvi szleng gyüjtése több szempontból is eltér a beszélt, vagy írott magyar nyelvi anyag gyűjtésétől. Néhány gyűjtési módszer (kérdőíves vizsgálat, diktafon használata) alapvetően szóba sem 
jöhet, hogyha jelnyelvi elemeket szeretnénk gyújteni, épp ezért az egyetlen rögzítési mód, ami a kutatás során használható, a videofelvételek készítése, ez az eljárás viszont nem problémamentes.

Labov (1972, 209. o.) nevéhez füződik az úgynevezett „megfigyelői paradoxon”. A megfigyelői paradoxon abból adódik, hogy a nyelvhasználók nyelvi megnyilvánulásainak megfigyelésekor „Célunk, hogy megfigyeljük, hogyan beszélnek az emberek akkor, amikor nem figyeljük őket" (Trudgill 1997, 49. o.). Hogyha bekapcsolt videokamerával érkezünk egy beszélgetésre, akkor valószínű, hogy az adatközlők eleinte nem fognak tudni természetesen viselkedni, zavarban lesznek, feszengeni fognak. Fontos minimalizálni ezt a feszültséget, megpróbálni elérni azt, hogy megfeledkezzenek a kameráról, és a lehető legtermészetesebben viselkedjenek.

A megfigyelői paradoxon csökkentésének egyik módja, hogy igyekszünk olyan témákról kérdezni, amely a közösséget érdekli és érinti. A siket közösséget például célszerű lehet a hallássérülésükről kérdezni, arról, hogy hogyan élik meg a mindennapokban, mennyire érzik hátránynak, mi a véleményük az oktatásról, mit gondolnak magáról a jelnyelvről, milyen tapasztalataik vannak a hallókkal, stb.

Viszont az így születő jelnyelvi interjúkból nehéz lehet kiszűrni a szleng elemeket, így fontos lehet valamilyen konkrét módon is rákérdezni arra, hogy mit tekintenek ők maguk szlengnek. Ezzel viszont az az alapvető probléma, hogy a szlenget mint nyelvészeti fogalmat valószínúleg nem ismeri minden siket, ha érzik is, mi az, nem tudnak egyértelmű definíciót adni (nem feltétlenül a siketségük okán). Ha viszont egy kész definíció ismertetése alapján kérünk tőlük szleng elemeket, nem biztos, hogy (a nyelvi nehézségeik miatt) eredményes gyűjtést tudunk végezni. Az lehet a megoldása ennek a problémának, hogyha körültekintően választunk adatközlőket, és minimalizálni tudjuk a kommunikációs nehézségeket.

A fent felvetett problémák minimálisra csökkenthetők. Az egyik megoldás az lehet, hogyha a gyüjtést jelnyelvi tolmácsok segítségével végezzük el. Ők könnyen akadálymentesíthetik a siket-halló kommunikációt, és a jelenlétükben talán nem is olyan lámpalázasak a kamera előtt a siketek. Egy másik megoldás az lehet, ha jelnyelvi tolmácsokkal végezzük a gyűjtést (tehát őket kérjük fel adatközlőnek). Valószínűsíthetően ők sem szoronganak a kamera előtt, és a hangzó magyar nyelvnek is ismerik olyan jól a szerkezetét, hogy könnyen megértenek egy szlengdefiníciót, így egyszerúbben tudnak szleng jeleket mutatni, mint a siketek. Ennek a megoldásnak azonban több hátránya is van: a tolmácsok időbeosztása nagyon feszes, nehéz olyan jeltolmácsokat találni, akik szívesen részt vennének egy ilyen gyűjtésben, ráadásul még nehezebb olyan jeltolmácsot találni, aki anyanyelvi szinten használja a jelnyelvet.

Harmadik lehetőségként készülhet a gyüjtés jelnyelvoktatók segítségével. A jel- 
nyelvoktatók elég magas szinten ismerik a hangzó magyar nyelvet (használniuk kell nap mint nap az oktatás során), és anyanyelvként használják a jelnyelvet is. Szívügyük a jelnyelv, így szívesen segítenek az ilyen jellegű feladatokban, a velük való kommunikáció könnyebb, mint a többi sikettel, így tolmácsra sincsen szükség. Vannak nyelvészeti ismereteik, mert az oktatóképzés során kötelezően hallgatnak jelnyelvészetet, így ezen terület terminológiájában is jártasak, hozzá vannak szokva a kamerához (általában saját óráikra is maguk készítik a videókat). Az anyaggyüjtésben tehát jelnyelvi oktatók segítségét is kérhetjük. Ez viszont felveti azt a problémát, hogy a jelnyelvoktatók a jelnyelvhasználó közösségen belül valamelyest „kibic”-nek számítanak, hiszen kevéssé szabályosan használják a jelnyelvet, mint a csoport belső tagjai (Sándor, 1995).

A jelnyelvi anyaggyűjtés első lépéseként elengedhetetlen a siketkultúra tanulmányozása, a jelnyelv minél magasabb szintű elsajátítása. A gyüjtés elején fontos lehet minél jobban bekerülni a siket közösségbe, minél több sikettel találkozni, beszélgetni. Ezek a beszélgetések tulajdonképpen szociolingvisztikai interjúként is funkcionáltak, habár videofelvétel nem készült róluk, csak jegyzetek. A siketekkel való beszélgetések során kiderült, hogy legtöbben nem ismerik a szleng fogalmát, nem tudnának definíciót adni rá.

Azok, akik ismerik a szleng terminust, és van róla fogalmuk, hogy mit jelent, direkt kérdésekre is tudnak választ adni - például: „Milyen szleng jele(ke)t ismersz a ...ra?” vagy „Van szleng jel a ...-ra? típusú kérdésekre is válaszolhatnak. Ez a gyüjtési módszer rávilágított arra, hogy a hangzó magyar nyelv szlengje és a magyar jelnyelvi szleng részben fedi egymást. A következő témakörök kerültek fókuszba a gyűjtés során: hallók-hallássérültek, iskola, ismerkedés, flört, technika, szórakozás, ételek, érzelmek, sport, öltözködés, külső, szexualitás, vita, emberi kapcsolatok, betegség, testrészek, hobbi, tudatmódosító szerek.

Időnként nehézséget okozott a jelek szleng voltának eldöntése, például a szitokszavak (azaz „szitokjelek”) esetében, de végül - az adatközlők véleményére alapozva - ezek is bekerültek a korpuszba. Az összegyűjtött jelekről lista készült, ez szolgál a szótár alapjául.

Ötven jel összegyűjtése után elkezdődött a jelnyelvi szótár készítése. A jelnyelvi szlengszótár (Net9) szócikkeinek felépítése csak részben illeszkedhet a klasszikus nyomtatott szótárak szócikkeinek felépítéséhez. Mivel a szótár egyrészt jelszlengmagyar kétnyelvű szótár, másrészt egynyelvű jelnyelvi szótár is, a szócikkekben szerepel:

- a szlengjel neve,

- videofelvétel a jelről,

- a szlengjel neutrális megfelelőjének neve (amennyiben van),

- videofelvétel a szlengjel neutrális megfelelőjéről,

- a szófaj, 
- a jelentésárnyalat (ahol megállapítható),

- mind a szlengjelet mind annak neutrális megfelelőjét tartalmazó példamondatok.

Lehetnek olyan szócikkek, ahol a szlengjel neutrális megfelelője a jelentésmegadásban segít, lehetnek olyan szócikkek, ahol a neutrális pár csak a kontraszt miatt szerepel, és lehetnek olyan szócikkek is, ahol nem lesz a szlengjelnek neutrális megfelelöje, itt a példamondat segít a jelentésmegadásban.

Mivel a hangzó és a jelnyelvi szleng csak részben fedi egymást, adódhatnak fordítási problémák. Előfordulhat, hogy a szlengjelnek van szleng megfelelője a hangzó nyelvben, viszont előfordulhat, hogy csak körülírással adható meg a jelentése, ilyenkor pedig nehezen érzékeltethető a fordításban a stílusárnyalat. Ebben az esetben példamondatok segíthetnek, így a fordításbeli problémák ellenére is meggyőző lesz az, hogy az adott jel a jelnyelvben szlengnek minősül.

A szótárba jelkapcsolatok is kerülhetnek. A jelnyelvi szótárakra általában jellemző, hogy a szavakat tematikus csoportba rendezve dolgozzák fel. Megjegyzés: a hangzó nyelvi szlenget feldolgozó szótárak közül is létezik olyan, amely tematikus csoportokba rendezi a gyüjtött anyagot (például: Hoffmann, 1996). Ennek az az előnye, hogy egyszerűbben áttekinthetők egy-egy témakör szavai, viszont mindig felveti azt a problémát, hogy bizonyos elemek nem férnek bele egy kate- góriába sem, így általában születik egy „egyéb” kategória. Ezt elkerülendő maga a jelnyelvi szlengszótár a szócikkeket a szleng jelek hangzó magyar nyelvi megfelelőinek alfabetikus sorendjében dolgozza fel.

A jelnyelvi szótárakra általában jellemző, hogy a szavakat tematikus csoportba rendezve dolgozzák fel. Ennek az az előnye, hogy egyszerűbben áttekinthetők egy-egy témakör szavai, viszont mindig felveti azt a problémát, hogy bizonyos elemek nem férnek bele egy kategóriába sem, így általában születik egy „egyéb” kategória. Ezt elkerülendő a jelnyelvi szlengszótár a szócikkeket alfabetikus sorendben dolgozza fel. Mivel minden egyes elem kereshető, a tematikus csoportosítás hiánya nem jelenthet problémát.

\section{ZÁRÓGONDOLATOK}

A hazai jelnyelvi szleng még kevéssé kutatott, korábban nem készült még sem nyomtatott, sem digitális formában gyűjtemény a magyar jelnyelv szleng jeleiről. A jelnyelvi anyaggyűjtés némileg eltér a hangzó nyelvi anyaggyújtéstől: nagyobb szerepet kap például a megfelelő digitális eszközök használata, s az adatközlők körültekintő kiválasztása. A jelnyelvi oktatók segítsége rendkívül hasznos lehet az ilyen jellegű gyűjtések során. A jelnyelvi szótárak készülhetnek nyomtatott, vagy online formában, az online változat számos előnye miatt a magyar jelnyelvi szlengszótár (Net9) is ilyen módon készül. 
A magyar jelnyelv szleng elemeinek további gyüjtése és a szótár folyamatos fejlesztése mellett számos kérdés vizsgálatára nyílhat még lehetőség a jelnyelvi szlenggel kapcsolatban. Például:

1) Egy-egy szlengjel idegen jelnyelvből átvett jövevényjel-e, vagy belső keletkezésû?

2) A jeleknek van-e neutrális megfelelője, vagy sem?

3) A jel esetleges neutrális párjához képest a kollokviális/szleng jel milyen eltérést hordoz?

4) A hét magyar jelnyelvjárás melyikében használják a jeleket?

5) Hol használnak hasonló jelentéstartalommal más jelet?

6) A szlengjel más jelentésben is használatos-e?

Felmerülnek még a kollokviális és szleng jelekkel kapcsolatban egyéb kérdések is, például hogy a siketiskolákban hogyan alakul a jelnyelvi szleng, hogy vannak-e tipikus használói a szlengnek, hogy van-e eltérés a siket családba született és a halló családba született siketek jelnyelvi szlenghasználatában.

\section{IRODALOM}

Baranyai A. és Vincze T. (2007): Vaker. Csimota Könyvkiadó, Budapest.

Berke, J. (2015): Using Name Signs for Personal Names. How do I get one? Letöltés: 2016. április 13. Web: deafness.about.com/od/expressionan dfun/a/signnames.htm
Moody, B. (1986): La langue des signes Tome II Dictionnaire bilingue élémentaire. Paris: Ellipses.

Hines, B. (2015): The Comprehension of Idioms in the Deaf Culture. In: Unconventional Wisdom: University of Montevallo McNair Scholars Research Journal, Volume III. Montevallo 16-26.

Hoffmann O. (1996): Mini-tini szótár. Janus Pannonius Tudományegyetem Továbbképző Központ University Press, Pécs.

Iván V. (2014): Így küld el a fenébe egy siket ember. NLCafé. Letöltés: 2016.04.13. Web: http://www.nlcafe.hu/foto/20 140801/jelnyelv-szleng-siket-fiatalok/

Jaxon, R.: How to Use ASL Slang (American Sign Language Slang) Letöltés: 2016. 12.11. Web: https://snapguide.com/ guides/use-asl-slang-american-signlanguage-slang/

Kis T. (1992): Bakaduma. A mai magyar katonai squleng szótára. Zrínyi Kiadó, Budapest.

Kis T. (2006): Is Slang a Linguistic Universal? [Nyelvi univerzálé-e a szleng?]. Revue d' Études Françaises 11. 125-141. Letölés: 2016.04.6. Web: http://mnytud.arts.klte.hu/szleng/tan ulmanyok/szluniv_eng.htm

Labov, W. (1972): Sociolinguistic patterns. Philadelphia (USA): University of Pennsylvania Press.

Lancz E. (1999): A magyar jelnyelv szótára. Siketek és Nagyothallók Országos Szövetsége, Budapest. 
Net1: Workshop on American Sign Language Slang and Colloquialisms Part 1. Letöltés: 2016.12.06. Web: http://wsrid.com/ event-1790687

Net2: Shannon, Rogan: A Deaf Perspective: ASL Signs and Slang | ft. Ren Putz. Letöltés: 2016.12.11. Web: https://www.youtube.com/watch?v= K2iRwQJh9dk

Net3: Sign Language Slang. Letöltés: 2016. 12. 11. Web: https://www.youtube. $\mathrm{com} / \mathrm{watch} ? \mathrm{v}=\mathrm{mSK}$ snxbTVb0

Net4: SigningSavryv. Letöltés: 2016. 12. 12. Web: https://www.signingsavvy.com/ wordlist/3371/idioms

Net5: American Sign Language Video Dictionaries and Quizzes. Letöltés: 2016.12.12. Web: http://www.aslpro. com/cgi-bin/aslpro/phrases.cgi

Net6: Spread the sign. Letöltés: 2020.09.28. Web: https://www.spreadthesign.com Net7: A Hallatlan Alapitvány jelnyelvi szótára. Letöltés: 2020.09.08. Web: https:// www.hallatlan.hu/c/jelek/

Net8: JelEsély jelnyelvi szótár. Letöltés: 2020.09.28. Web: http://szotar2.jel esely. hu

Net9: Jelnyelvi szlengszótár. Letöltés: 2020.09.28. Web: https://jelnyelv szleng.blog.hu/

Odaloš, P. (1999): Mi a szociolektus és mi a szleng? In: Fenyvesi A., Kis T. és Várnai J. Sz. (szerk.): Mi a szleng? Kossuth Egyetemi Kiadó, Debrecen. 4150.

Panse, S. (2012): How to Sign Popular Idioms. Letöltés: 2016.12.12. Web: http://www.brighthubeducation.com/ studying-a-language/40538-idioms-inamerican-sign-language/

Penttinen, A. (1984): Sotilasslangin sanakirja. Helsinki: Porvoo WSOY.

Radutzky, E. (1992): Dizionario bilingue elementare della lingua italiana dei segni. Bologna: Kappa.

Rizzo, M. (2008): At Home with Marlee Matlin. People, Vol.69. No.16. 99-100.

Sándor K. (1995): Az élőnyelvi vizsgálatok és az iskola: a kisebbségi kétnyelvűség. Regio: Kisebbségtudományi Szemle, 1995 (4). 121-148. o.

Sheffield, M., Duncan, A. \& Strasser, A. (2015): Internet Slang Meets American Sign Language. Letöltés: 2016.12.11. Web: http://www.hopesandfears.com /hopes/now/internet/168477-interne t-american-sign-language

Sternberg, M. L. A. (1998): American Sign Language Dictionary, Third Edition. New York: Harper Collins Publishers.

Stokoe, W. C. (1960): Sign Language Structure: An Outline of Visual Communication Systems of the American Deaf. Journal Of Deaf Studies And Deaf Education, 1960, 10 1, 3-37.

Tender, T. (1997): Az észt szleng és kutatása. In: Kis T. (szerk.): A sqlengkutatás útjai és lehetóségei. Kossuth Egyetemi Kiadó, Debrecen. 91-119.

Triantaphullides, G. (1987): Systema bellenikon neumaton. Thessalonika: Hoi Philoi Ton Kophalalon Thessalonikes 
Trudgill, P. (1997): Bevezetés a nyelv és társadalom tanulmányozásába. JGyTF Kiadó, Szeged.

Tucker, B. P. (2002): A csend hangjai. Bastei Budapest Kiadói Kft., Budapest.

Van James, T. \& Allison, O. (2011): Dirty Sign Language: Everyday Slang from
"What's Up?" to "F*\%\# Off!" (Dirty Everyday Slang). New York: Ulysses Press.

Vasák I. (2005): A világ siket szemmel. Fogyatékosok Esélye Közalapítvány, Budapest. 